\title{
DETERMINATION OF POTENTIAL AND ACTUAL EVAPOTRANSPIRATION IN WATERSHED, USING MATHEMATICAL MODELS
}

\section{DETERMINACIÓN DE LA EVAPOTRANSPIRACIÓN POTENCIAL Y REAL EN CUENCA HIDROGRÁFICA, UTILIZANDO MODELOS MATEMÁTICOS}

\section{Javier Alfonso Cárdenas Gutiérrez ${ }^{1}$}

Jose Leonardo Jacome Carrascal ${ }^{2}$

\section{Mawency Vergel Ortega ${ }^{3}$}

Colombia

\section{RESUMEN}

En esta investigación se analiza el cálculo de la evapotranspiración real en cuencas

$1 \quad$ Engineering Faculty Universidad Francisco de Paula Santander, Cúcuta, Norte de Santander, Colombia Email- javieralfonsocg@ufps.edu.co Orcid: https://orcid. org/0000-0002-9894-017

$2 \quad$ Engineering Faculty

Universidad Francisco de Paula Santander, Cúcuta, Norte de Santander, Colombia

Email- jose.jacome@ufps.edu.co orcid: https://orcid. org/0000-0002-6022-6891

3 Universidad Francisco de Paula Santander, Cúcuta, Norte de Santander, Colombia

Email: mawencyvergel@ufps.edu.co orcid: https://orcid. org/0000-0001-8285-2968 hidrográficas, se toma como referente la quebrada Aguablanca, ubicada en el municipio de Bochalema, Norte de Santander-Colombia, donde se evalúa el balance hidrológico de esta cuenca a partir de la determinación de cálculos detallados de cuatro modelos matemáticos, para posteriormente evaluar el balance hidrológico de esta cuenca, con el fin de poder hacer una mejor administración de estos recursos, así como del uso del suelo, apostando al desarrollo de una sociedad ecológicamente sostenible y de bajo impacto ambiental. Los valores de evapotranspiración potencial y real, según el 
modelo más optimo ETP Thorwaite $874 \mathrm{~mm} / \mathrm{año}$ ETR $43712 \mathrm{~mm} / \mathrm{año}$, Cenicafe $712.81 \mathrm{~mm} / \mathrm{año}$ ETR $612.1 \mathrm{~mm} / \mathrm{año}$ Turc ETR $884.83 \mathrm{~mm} / \mathrm{año}$ cuota ETR $825 \mathrm{~mm} / \mathrm{año}$.

PALABRAS CLAVE - Evapotranspiración, Cuenca, Thorwaite, Cenicafe, Turc, Conteo.

\section{ABSTRACT}

In this research, it is analyzed the calculation of real evapotranspiration in hydrographic basins, it is taken as a reference the Aguablanca Creek, located in the municipality of Bochalema, North of Santander-Colombia, where it is evaluated the hydrologic balance of this basin from the determination of detailed calculations of four mathematical models, to later evaluate the hydrologic balance of this basin, with the purpose of being able to make a better administration of these resources, as well as the use of the soil, betting on the development of an ecologically sustainable society with low environmental impact. The values of potential and real evapotranspiration, according to the most optimal model ETP Thorwaite $874 \mathrm{~mm} /$ year ETR 43712 mm/year, Cenicafe $712.81 \mathrm{~mm} /$ year ETR $612.1 \mathrm{~mm} /$ year Turc ETR $884.83 \mathrm{~mm} /$ year quota ETR $825 \mathrm{~mm} /$ year.

KEYWORDS Evapotranspiration, Watershed, Thorwaite, Cenicafe, Turc, Countage.

\section{INTRODUCTION}

Evapotranspiration, is an important component for the correct analysis of the water balance, so that its estimation allows a correct analysis for the management of water resources, forest management, territorial planning and crop irrigation [6] [11] [13]. Evapotranspiration is a complex process within the hydrological field, since it directly influences the amount of surface and ground water. It is a term that describes the evaporation and transpiration of a plant, from the earth's surface, to the atmosphere [10] [12].
However, due to human activities, the world changes daily due to the intense acceleration of global warming, which has a direct effect on the water cycle, one of the most vulnerable aspects of an ecosystem [3]. The hydrological cycle has been affected at different times throughout history, but with the current deterioration of resources, many rivers have been on a downward trend, making the existence of water more and more difficult [1].

Climate change intensifies the circulation of the hydrological cycle in the atmosphere, which in turn alters the patterns of precipitation and evapotranspiration [5], which is one of the most difficult variables to measure in the water balance [4].

Human activities, such as the consumption of fossil fuels, and the misuse of land, have generated a great impact on ecosystems, resulting in various extreme hydrological events (floods and droughts) which, as time passes, occur more intensely and frequently [2] [8] [14].

Therefore, the change in the time of evapotranspiration must be measured in order to know the health benefits of an ecosystem, as well as the availability of water and land uses [9] but the problem lies in the lack of longterm historical series, in order to be able to perform a relevant analysis, on precipitation and temperature data and thus be able to know the value of evapotranspiration [7].

In this way, the need to study the behavior of our river basins is of supreme importance, because in this way it will be possible to estimate the amount of resources that we have and be able to establish a more adequate planning and management of these resources[15].

\section{METHODOLOGY}

Four different methods were used to calculate potential evapotranspiration. 


\subsection{Thorwaite model}

This method uses the monthly temperature parameters and the average monthly hours of light, data provided by IDEAM. We find as main variables the average temperature of the month and the hours of light.

Table 1. Average monthly temperature and hours of light per month.

\begin{tabular}{|c|c|c|}
\hline MONTH & $\begin{array}{c}\text { AVERAGE } \\
\text { TEMPERATURE }\end{array}$ & $\begin{array}{c}\text { LIGHT } \\
\text { HOURS }\end{array}$ \\
\hline JANUARY & 18.26 & 11,375 \\
\hline FEBRUARY & 18.69 & 11,865 \\
\hline MARCH & 19.13 & 12,045 \\
\hline APRIL & 19.48 & 12,295 \\
\hline MAY & 19.73 & 12,455 \\
\hline JUNE & 19.57 & 12,325 \\
\hline JULY & 19.42 & 12,505 \\
\hline AUGUST & 19.65 & 12,355 \\
\hline SEPTEMBER & 19.58 & 12,185 \\
\hline OCTOBER & 19.39 & 11,95 \\
\hline NOVEMBER & 19.08 & 11,78 \\
\hline DECEMBER & 18.48 & 11,7 \\
\hline
\end{tabular}

However, these are not the only variables.

Thorwaite's potential evapotranspiration equation is:

$$
E T p=16 *\left(10 * \frac{T m}{I}\right)^{a}
$$

Where:

$\mathrm{Tm}$ is the average monthly temperature in $\mathrm{C}$

I : annual heat index

$\mathrm{I}=$ Summation $(\mathrm{ij}) ; \mathrm{j}=1, \ldots, 12$ (which is calculated by adding the twelve monthly heat indexes).

$\mathrm{ij}=(\mathrm{tmj} / 5) 1.514$

a : parameter that is calculated from I according to the expression:

$a=0,000000675 \times\left.\right|^{3}-0,0000771 \times\left.\right|^{2}+0,01792 \times \mid+$ 0,49239
And finally we have to:

$$
E T P_{\text {correctec }}=E T P_{\text {thorwaite }} * L
$$

Where:

$$
L=\frac{N \text { o days of the month }}{30} * \frac{N \text { o sunshine hours }}{12}
$$

\subsection{Cenicafe Model}

This model allows calculating the potential evapotranspiration (PET) in a simple way, because in this equation the PET only depends on the elevation above sea level. The equation was the product of a regression elaborated by Cenicafé between the values of evapotranspiration and the height above sea level

$$
E T P_{\text {cenicafe }}=1017.17 \exp (-0.0002 h)
$$

\subsection{Turc Model}

In the Turc model, a mass balance is established, resulting in the following expression:

$$
E T R=\frac{P}{\sqrt{0.9+\frac{P^{2}}{L^{2}}}}
$$

Where, ETR, is the actual evapotranspiration $(\mathrm{mm} /$ year), $\mathrm{P}$ is the average precipitation of the basin during one year ( $\mathrm{mm} /$ year) and $\mathrm{T}$ is the average annual temperature in ${ }^{\circ} \mathrm{C}$.

When the $P / L$ ratio $>0.316$, equation 6 is used where $L$ is represented by the following equation:

$$
L=300+25 T+0.05 T^{3}
$$

If $P / L<0.316$, then $E T R=P$.

\subsection{Countage Model}


This model is based on the meteorological conditions of the basin. Where an estimation of the real evapotranspiration is made as a function of the precipitation and the temperature of the:

$$
E T R=P-\lambda \mathrm{P}^{2}
$$

Where ETR is the actual evapotranspiration in $\mathrm{mm} /$ year and $\mathrm{P}$ is the precipitation in $\mathrm{mm} /$ year. The lambda factor is a temperature-dependent factor.

$$
\lambda=\frac{1}{0.8+0.14 T}
$$

$\mathrm{T}$ is the value of the average annual temperature in $\mathrm{C}^{\circ}$. Equation 9 is only applicable for $\mathrm{P}$ values between $(8 \lambda)^{-1}$ and $(2 \lambda)^{-1}$. If rainfall is less than $(8 \lambda)^{-1}$ then:

$$
E T R=P
$$

\section{Results and Discussions}

3.1 Thorwaite model. The results of equations 2 , 3 and 5 are in the following tables:

Table 2. Result of Equation 2

\begin{tabular}{|c|c|c|}
\hline MONTH & $\begin{array}{c}\text { AVERAGE } \\
\text { TEMPERATURE }\end{array}$ & $\mathrm{I}$ \\
\hline JANUARY & 18.26 & 7.17 \\
\hline FEBRUARY & 18.69 & 7.42 \\
\hline MARCH & 19.13 & 7.69 \\
\hline APRIL & 19.48 & 7.90 \\
\hline MAY & 19.73 & 8.05 \\
\hline JUNE & 19.57 & 7.95 \\
\hline JULY & 19.42 & 7.86 \\
\hline AUGUST & 19.65 & 8.00 \\
\hline SEPTEMBER & 19.58 & 7.96 \\
\hline OCTOBER & 19.39 & 7.84 \\
\hline NOVEMBER & 19.08 & 7.65 \\
\hline DECEMBER & 18.48 & 7.30 \\
\hline
\end{tabular}

The total value of I is given by the sum of all the values, therefore, $I=92.80$.

Thus, the value of a:

$$
\begin{gathered}
a=0,000000675 \times 92.80^{3}-0,0000771 \times 92.80^{2} \\
+0,01792 \times 92.80+0,49239=2.03
\end{gathered}
$$

The values of actual evapotranspiration would be of the order:

Table 3. Potential evapotranspiration values according to the month.

\begin{tabular}{|c|c|}
\hline MONTH & ETP \\
\hline JANUARY & 63.99 \\
\hline FEBRUARY & 67.04 \\
\hline MARCH & 70.27 \\
\hline APRIL & 72.88 \\
\hline MAY & 74.78 \\
\hline JUNE & 73.56 \\
\hline JULY & 72.45 \\
\hline AUGUST & 74.17 \\
\hline SEPTEMBER & 73.66 \\
\hline OCTOBER & 72.20 \\
\hline NOVEMBER & 69.87 \\
\hline DECEMBER & 65.52 \\
\hline
\end{tabular}

The factor $L$ in equation 5 is now calculated from the data in Table 1.

Table 4. Factor $\mathrm{L}$

\begin{tabular}{|c|c|c|c|}
\hline MONTH & $\begin{array}{c}\text { DAYS } \\
\text { OF THE } \\
\text { MONTH }\end{array}$ & $\begin{array}{c}\text { HOURS } \\
\text { OF } \\
\text { LIGHT }\end{array}$ & L \\
\hline JANUARY & 31.000 & 11.500 & 0.990 \\
\hline FEBRUARY & 28.000 & 12.000 & 0.933 \\
\hline MARCH & 31.000 & 12.000 & 1.033 \\
\hline APRIL & 30.000 & 12.500 & 1.042 \\
\hline MAY & 31.000 & 12.500 & 1.076 \\
\hline JUNE & 30.000 & 12.500 & 1.042 \\
\hline JULY & 31.000 & 12.500 & 1.076 \\
\hline AUGUST & 31.000 & 12.500 & 1.076 \\
\hline SEPTEMBER & 30.000 & 12.000 & 1.000 \\
\hline OCTOBER & 31.000 & 12.000 & 1.033 \\
\hline NOVEMBER & 30.000 & 12.000 & 1.000 \\
\hline DECEMBER & 31.000 & 11.500 & 0.990 \\
\hline
\end{tabular}


Finally, the corrected evapotranspiration resulting from equation 4 .

Table 5. Corrected potential evapotranspiration.

\begin{tabular}{|c|c|c|c|}
\hline MONTH & $\begin{array}{c}\text { UNCORREC- } \\
\text { TED ETP }\end{array}$ & L & $\begin{array}{c}\text { ETP } \\
\text { CORREC- } \\
\text { TED }\end{array}$ \\
\hline JANUARY & 63.99 & 0.990 & 63.37 \\
\hline FEBRUARY & 67.04 & 0.933 & 62.57 \\
\hline MARCH & 70.27 & 1.033 & 72.61 \\
\hline APRIL & 72.88 & 1.042 & 75.92 \\
\hline MAY & 74.78 & 1.076 & 80.50 \\
\hline JUNE & 73.56 & 1.042 & 76.63 \\
\hline JULY & 72.45 & 1.076 & 77.98 \\
\hline AUGUST & 74.17 & 1.076 & 79.84 \\
\hline SEPTEMBER & 73.66 & 1.000 & 73.66 \\
\hline OCTOBER & 72.20 & 1.033 & 74.61 \\
\hline NOVEMBER & 69.87 & 1.000 & 69.87 \\
\hline DECEMBER & 65.52 & 0.990 & 64.88 \\
\hline
\end{tabular}

Finally, for the calculation of actual evaporation, the Budyko equation:

$E T R=\left\{E T P * P * T A N\left(\frac{P}{E T P}\right)\left[1-\operatorname{COS}\left(\frac{E T P}{P}\right)+\operatorname{SEN}\left(\frac{E T P}{P}\right)\right]\right\}^{1 / 2}$

Where with a total potential evapotranspiration value of $872.43 \mathrm{~mm} /$ year and an average precipitation of $1327.6 \mathrm{~mm} /$ year, data provided by IDEAM.

It gives a total result of real evapotranspiration with equation 11 of $712 \mathrm{~mm} /$ year.

\subsection{Cenicafe model}

The value of potential evapotranspiration according to equation 6 , taking into account the average height of this basin, which is 1777.44 $\mathrm{m}$, shows the following result:

$E T P_{\text {cenicafe }}=1017.17 \operatorname{EXP}(-0.0002 * 1777.44)=712.81 \mathrm{~mm} / \mathrm{año}$

Using again the previous precipitation value and using equation 11 , a result of real Evapotranspiration of $612.10 \mathrm{~mm} /$ year is obtained.

\subsection{Turc Model}

For this model, the parameter $L$ is first calculated, represented by equation 8 and with the temperature value $19.3^{\circ} \mathrm{C}$

$$
L=300+25 * 19.3+0.05 * 19.3^{3}=1141.95
$$

The $P / L$ ratio is calculated

$$
\frac{P}{L}=1327.9 / 1141.95=1.16
$$

Because it is greater than 0.316, then the calculation of actual evapotranspiration according to equation 7

$$
E T R=\frac{1327.9}{\sqrt{0.9+\frac{1327.9^{2}}{1141.95^{2}}}}=884.83 \mathrm{~mm} / \mathrm{año}
$$

\subsection{Countange model}

The first step of this model is to calculate the lambda value, established in equation 10 , taking the temperature value, mentioned above, as a reference:

$$
\lambda=\frac{1}{0.8+0.14 * 19.3}=0.285
$$

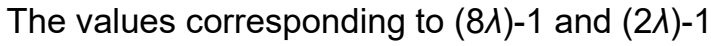
equal to 0.438 and 1.754 expressed in meters, and the precipitation is equal to $1327.9 \mathrm{~mm}$ or $1,327 \mathrm{~m}$, therefore, it is in the range.

Actual evapotranspiration is calculated as defined by equation 10 .

$$
E T R=1.327-0.285 * 1.327^{2}=0.825
$$

\section{CONCLUSION}

The calculation of the real evapotranspiration is one of the most important parameters to establish the water balance of a basin, in this case of study, the basin of the Aguablanca stream located in the municipality of Bochalema, Norte de Santander, Colombia.

The values of potential and actual evapotranspiration, according to the model are. 
Table 6 . Results.

\begin{tabular}{|c|c|c|}
\hline MODEL & ETP $(\mathrm{mm} / \mathrm{año})$ & ETR $(\mathrm{mm} / \mathrm{año})$ \\
\hline Thorwaite & 874.43 & 712 \\
\hline Cenicafe & 712.81 & 612.1 \\
\hline Turc & & 884.83 \\
\hline Countange & & 825 \\
\hline
\end{tabular}

To be able to carry out a water balance calculation for this river basin would have an impact on the society within this zone, because it would allow a better administration of the resources, allowing this community to develop as a low impact society.

In this case, due to the differences between evapotranspirations, one of the recommendations would be to use the highest value of real evapotranspiration for water supply calculations with respect to human use and crops in order to have a safety factor. Similarly, when designing structures that are directly related to the riverbed in this basin, use the lowest value of evapotranspiration.

\section{BIBLIOGRAFIC REFERENCES}

[1] Bai, M., Shen, B., Song, X., Mo, S., Huang, L., \& Quan, Q. (2019). Multi-Temporal Variabilities of Evapotranspiration Rates and Their Associations with Climate Change and Vegetation Greening in the Gan River Basin, China. Water, 11(12), 2568. doi:10.3390/w11122568

[2] Chu, R., Li, M., Islam, A., Fei, D., \& Shen, S. (2019). Attribution analysis of actual and potential evapotranspiration changes based on the complementary relationship theory in the Huai River basin of eastern China. International Journal Of Climatology, 39(10), 40724090. doi: $10.1002 / j o c .6060$

[3] Guan, X., Zhang, J., Yang, Q., \& Wang, G. (2020). Changing characteristics and attribution analysis of potential evapotranspiration in the Huang-HuaiHai River Basin, China. Meteorology And Atmospheric Physics. doi: 10.1007/ s00703-020-00741-6

[4] Jian, D., Li, X., Sun, H., Tao, H., Jiang, T., Su, B., \& Hartmann, H. (2018). Estimation of Actual Evapotranspiration by the Complementary TheoryBased Advection-Aridity Model in the Tarim River Basin, China. Journal of Hydrometeorology, 19(2), 289-303. doi:10.1175/jhm-d-16-0189.1

[5] Liu, W., \& Liu, L. (2019). Analysis of Dry/Wet Variations in the Poyang Lake Basin Using Standardized Precipitation Evapotranspiration Index Based on Two Potential Evapotranspiration Algorithms. Water, 11(7), 1380. doi:10.3390/ w11071380

[6] Liu, Z., Yao, Z., \& Wang, R. (2019). Simulation and evaluation of actual evapotranspiration based on inverse hydrological modeling at a basin scale. CATENA, 180, 160168. doi:10.1016/j.catena.2019.03.039

[7] Onyutha, C., Acayo, G., \& Nyende, J. (2020). Analyses of Precipitation and Evapotranspiration Changes across the Lake Kyoga Basin in East Africa. Water, 12(4), 1134. doi:10.3390/w12041134

[8] Pan, Xu, Xuan, Gu, \& Bai. (2019). Appropriateness of Potential Evapotranspiration Models for Climate Change Impact Analysis in Yarlung Zangbo River Basin, China. Atmosphere, 10(8), 453. doi:10.3390/atmos 10080453 
[9] Roche, J. W., Goulden, M. L., \& Bales, R. C. (2018). Estimating evapotranspiration change due to forest treatment and fire at the basin scale in the Sierra Nevada, California. Ecohydrology, e1978. doi:10.1002/eco.1978

[10] Wang, Y., Luo, Y., \& Shafeeque, M. (2019). Using Gaussian Function to describe the seasonal courses of monthly precipitation and potential evapotranspiration across the Yellow River Basin, China. Journal of Hydrometeorology. doi:10.1175/ jhm-d-19-0019.1

[11] Wu, X., \& Meng, D. (2016). Analysis of temporal and spatial characteristics about surface actual Evapotranspiration in Haihe river basin based on MODIS. 2016 4th International Workshop on Earth Observation and Remote Sensing Applications (EORSA). doi:10.1109/ eorsa.2016.7552850

[12] Yadeta, D., Kebede, A., \& Tessema, N. (2020). Potential evapotranspiration models evaluation, modelling, and projection under climate scenarios, Kesem sub-basin, Awash River basin, Ethiopia. Modeling Earth Systems and Environment. doi:10.1007/s40808-02000831-9

[13] Zeng, R., \& Cai, X. (2016). Climatic and terrestrial storage control on evapotranspiration temporal variability: Analysis of river basins around the world. Geophysical Research Letters, 43(1), 185-195. doi:10.1002/2015gl066470

[14] Zhang, D., Li, Z., Tian, Q., \& Feng, Y. (2019). Drought Assessment in a Semi-Arid River Basin in China and its Sensitivity to Different Evapotranspiration Models. Water,
11(5), 1061. doi:10.3390/w11051061

[15] Zhang, Y., He, B., Guo, L., Liu, J., \& Xie, $X$. (2019). The relative contributions of precipitation, evapotranspiration, and runoffto terrestrial water storage changes across 168 river basins. Journal of Hydrology, 579, 124194. doi:10.1016/j. jhydrol.2019.124194 